\title{
Influence of the Temperature of Salt Brine on Salt Uptake by Ragusano Cheese ${ }^{1}$
}

\author{
C. Melilli, ${ }^{\star}$ D. M. Barbano,† G. Licitra, ${ }^{\star} \ddagger$ G. Portelli, ${ }^{\star}$ G. Di Rosa, ${ }^{\star}$ and S. Carpino \\ ${ }^{*}$ CoRFiLaC, \\ Regione Siciliana, \\ 97100 Ragusa, Italy \\ †Northeast Dairy Food Research Center, Department of Food Science, \\ Cornell University, Ithaca, NY 14853 \\ ‡Dipartimento di Scienze Agronomiche, Agrochimiche e delle Produzioni Animali, \\ Catania University, Via Valdisavoia 5, 95100 Catania, Italy
}

\begin{abstract}
The influence of temperature $(12,15,18,21$, and $24^{\circ} \mathrm{C}$ ) of saturated brine on salt uptake by 3.8 -kg experimental blocks of Ragusano cheese during $24 \mathrm{~d}$ of brining was determined. Twenty-six 3.8-kg blocks were made on each of three different days. All blocks were labeled and weighed prior to brining. One block was sampled and analyzed prior to brine salting. Five blocks were placed into each of five different brine tanks at different temperatures. One block was removed from each brine tank after 1, 4, 8, 16, and $24 \mathrm{~d}$ of brining, weighed, sampled, and analyzed for salt and moisture content. The weight loss by blocks of cheese after $24 \mathrm{~d}$ of brining was higher, with increasing brine temperature, and represented the net effect of moisture loss and salt uptake. The total salt uptake and moisture loss increased with increasing brine temperature. Salt penetrates into cheese through the moisture phase within the pore structure of the cheese. Porosity of the cheese structure and viscosity of the water phase within the pores influenced the rate and extent of salt penetration during 24 $\mathrm{d}$ of brining. In a previous study, it was determined that salt uptake at $18^{\circ} \mathrm{C}$ was faster in $18 \%$ brine than in saturated brine due to higher moisture and porosity of the exterior portion of the cheese. In the present study, moisture loss occurred from all cheeses at all temperatures and most of the loss was from the exterior portion of the block during the first $4 \mathrm{~d}$ of brining. This loss in moisture would be expected to decrease porosity of the exterior portion and act as a barrier to salt pene-
\end{abstract}

Received January 9, 2003.

Accepted March 11, 2003.

Corresponding author: D. M. Barbano; e-mail:dmb37@cornell.edu.

${ }^{1}$ Use of names, names of ingredients, and identification of specific models of equipment is for scientific clarity and does not constitute any endorsement of product by authors, Cornell University, the Northeast Dairy Foods Research Center, CoRFiLaC, and Dipartimento di Scienze Agronomiche, Agrochimiche e delle Produzioni Animali, Catania University. tration. The moisture loss increased with increasing brine temperature. If this decrease in porosity was the only factor influencing salt uptake, then it would be expected that the cheeses at higher brine temperature would have had lower salt content. However, the opposite was true. Brine temperature must have also impacted the viscosity of the aqueous phase of the cheese. Cheese in lower temperature brine would be expected to have higher viscosity of the aqueous phase and slower salt uptake, even though the cheese at lower brine temperature should have had a more porous structure (favoring faster uptake) than cheese at higher brine temperature. Therefore, changing brine concentration has a greater impact on cheese porosity, while changing brine temperature has a larger impact on viscosity of the aqueous phase of the cheese within the pores in the cheese.

(Key words: brine temperature, salt uptake, Ragusano cheese)

\section{INTRODUCTION}

Ragusano cheese is a brine-salted, pasta-filata cheese that is still produced at the farm level in the Eastern region of Sicily. The cheese is made from raw milk and lactic acid is produced by natural milk microflora and desirable microflora present in the surface of the wooden cheese vat. Typically, Ragusano cheese is brine salted for the first $8 \mathrm{~d}$ at the farm, followed by continued brine salting at an aging center in saturated brine at $18^{\circ} \mathrm{C}$. When salt uptake by cheese during brining is too slow, early gas formation and off-flavor development occur due to the growth of undesirable bacteria. The level of undesirable bacteria is dependent on their initial level in the milk, and their growth is favored by low acid production during cheese making (Choisy et al., 1987) and slow salt penetration during brining. One component of a strategy to help control growth of undesirable gas producing bacteria is the use of a brining system that is able to quickly increase the salt content 
of the cheese. A previous study (Melilli et al., 2003) demonstrated that use of $18 \%$ salt brine instead of saturated brine (i.e., 26\%) for the first $8 \mathrm{~d}$ of $24 \mathrm{~d}$ of brine salting increased the rate of salt uptake, compared with $24 \mathrm{~d}$ in saturated brine. The cheese in $18 \%$ salt brine at $18^{\circ} \mathrm{C}$ achieved in $12 \mathrm{~d}$ the same salt content as cheese in saturated brine for $24 \mathrm{~d}$ at $18^{\circ} \mathrm{C}$. The increased rate of salt uptake with $18 \%$ brine compared with saturated brine was related to the impact of lower brine concentration on the moisture content and porosity of the cheese near the surface of the block. Brine with higher salt content causes a rapid loss of moisture from cheese near the surface of the block. Moisture loss causes shrinkage of the cheese structure and decreases porosity, which impedes moisture movement out and salt movement into the block. The use of $18 \%$ salt brine for the first 8 $\mathrm{d}$ delayed the moisture loss and cheese shrinkage at the exterior of the block and allowed more rapid salt penetration (Melilli et al., 2003). Use of $18 \%$ salt brine instead of saturated brine could be implemented at a farmhouse cheese making facility and have a major impact on reducing the frequency of quality defects caused by growth of undesirable gas producing bacteria.

Another strategy to control growth of undesirable gas-producing bacteria in the cheese might be to decrease brine temperature. Lower temperature would decrease the growth of these bacteria during brining and possibly reduce the chance of gas, but lower brine temperature would also be expected to reduce the rate of salt uptake by the cheese. The net effect of reducing brine temperature on gas production is not known. At the farm level, brine temperature can vary seasonally from 10 to $24^{\circ} \mathrm{C}$ and this can influence the salt uptake. Geurts et al. (1974) showed that for gouda cheese the salt diffusion at $20^{\circ} \mathrm{C}$ was higher by about 40 to $50 \%$ than at $12.5^{\circ} \mathrm{C}$. Turhan and Kaletunç (1992) found that for White cheese, a semi-hard pickled cheese (Carić, 1993), the salt penetration was slower with decreasing brine temperature because of decreased salt diffusivity.

The objective of the present study was to determine the impact of five different temperatures $(12,15,18$, 21 , and $24^{\circ} \mathrm{C}$ ) of saturated salt brine on the rate of salt uptake by Ragusano cheese.

\section{MATERIALS AND METHODS}

\section{Preparation of Brine}

A preliminary study was done to determine whether the salt concentration (wt/wt) of a saturated salt solution changes with temperature in the range of temperatures that could be used in this study. Saturated solutions of sodium chlorine in distilled water were made at temperatures from 4 to $24^{\circ} \mathrm{C}$. The total solids contents were determined by drying a 2 -g sample of each solution in a forced air oven at $100^{\circ} \mathrm{C}$ for $24 \mathrm{~h}$ (AOAC, 2000 , method number 33.2.44; 990.20). The salt concentration at $4,12,15,18,21$, and $24^{\circ} \mathrm{C}$ were all about $26.6 \%$ (wt/wt) and therefore for practical purposes the saturation concentration of $\mathrm{NaCl}$ across the range of temperature is constant.

The rate of salt uptake by the cheese is also influenced by the ratio of volume of brine to cheese. Zorilla and Rubiolo (1991) demonstrated with a mathematical model that the uptake of salt was slower when there was too much cheese in brine. They concluded that at a ratio of brine volume should be five times the volume of the cheese or greater, to ensure that the uptake of salt from brine would not be influenced by the amount of cheese in brine. Therefore, from that study, we estimated the volume of the brine needed for our experiment was $200 \mathrm{~L}$ at each temperature.

Fifteen days before the experiment, a used saturated brine was transported from a traditional aging center to CoRFiLaC's pilot plant, because it would contain a normal calcium content and have a normal $\mathrm{pH}$, compared to a freshly made brine. Calcium content of the brine was measured using a complexometric method (Kindstedt and Kosikowski, 1985). The initial salt brine had a calcium concentration $0.11 \%$ and a pH of 5.20 . The old brine was filtered and divided in five brine tanks. Each tank was placed in a temperature controlled room set at one of the following temperatures: $12,15,18,21$, and $24^{\circ} \mathrm{C}$. The salt brine was kept saturated by leaving immersed a container full of salt. Every day the salt brines were stirred and checked several times for temperature, salt concentration (using a Baumé hydrometer, 1 to $30^{\circ}$ Bé, Sacco s.r.l., Milano, Italy), and $\mathrm{pH}$.

\section{Milk for Cheese Making}

Twelve hundred liters of raw milk produced by Brown Swiss and mixed breed cows from two milkings were mixed in a stainless steel vat at $35^{\circ} \mathrm{C}$, and analyzed for fat, $\mathrm{CP}$, and lactose using an infrared milk analyzer (AOAC, 2000; method number 33.2.31; 972.16), for SCC using a fluorimetric method (AOAC, 2000; method number 17.13.01; 978.26), for the titratable acidity, and $\mathrm{pH}$. The average raw whole milk used in three cheese-making sessions had a titratable acidity of $0.153 \mathrm{~g}$ of lactic acid/100 $\mathrm{ml}$ and $\mathrm{a} \mathrm{pH}$ of 6.67 at $35^{\circ} \mathrm{C}$. The fat, $\mathrm{CP}$, and lactose content were $3.32,3.29$, and $4.84 \%$, respectively, with a SCC of $327,000 / \mathrm{ml}$.

\section{Cheese Making}

Ragusano cheese was manufactured using the procedures described by Melilli et al. (2003) but differing in 
the following aspects: the second cooking was about 138 min, and after $18 \mathrm{~h}$ of ripening at $18^{\circ} \mathrm{C}$ the $\mathrm{pH}$ of the curd was 5.30. After ripening the curd was cut into long, uniform, 1-cm thick slices that were weighed and divided into 26 batches ( $4 \mathrm{~kg}$ each). Three cheese makers stretched 26 batches of curd, to produce 26 blocks of cheese $(15.2 \times 15.2 \times 15.2 \mathrm{~cm})$. The weight of each block of cheese decreased during stretching from about 4 to $3.8 \mathrm{~kg}$. Each cheese was marked with a letter (treatment) and a number (sampling day) so that the cheese could be correctly identified in the brine tank. After forming the blocks, one of the 26 blocks was analyzed before brining. The remaining 25 blocks were divided in five groups and each group was placed into saturated salt brine at a different temperature $(12,15,18,21$, and $24^{\circ} \mathrm{C}$ ). The blocks were kept submerged for $24 \mathrm{~d}$.

\section{Sampling and Analysis of Cheese}

Cheeses were sampled at 0 time (before brining), 1 , 4, 8, 16, and $24 \mathrm{~d}$. Each experimental block of Ragusano cheese, on the sampling day, was weighed and divided in four portions P1, P2, P3, and P4, as described by Melilli et al. (2003), using a meat slicer (model 601003, Electrolux, Zanussi Italia s.p.a, Pordenone, Italy). Each of the four portions represented approximately $25 \%$ of the weight of the block of the cheese. The exterior portion (P1) represented all six faces of the block (approximately $0.6 \mathrm{~cm}$ thick). The P2 portion was removed (approximately $1 \mathrm{~cm}$ thick), after removal of the $\mathrm{P} 1$ portion, from all the six faces of the block, followed by removal of the P3 portion (approximately $1 \mathrm{~cm}$ thick). The cube remaining of about $10 \times 10 \times 10 \mathrm{~cm}$ was the central portion (P4).

Each portion (P1, P2, P3, and P4) was weighed, cut into cubes, and grated. Moisture content was determined by drying a $3-\mathrm{g}$ sample in a forced air oven at $100^{\circ} \mathrm{C}$ for $24 \mathrm{~h}$ (AOAC, 2000, method number 33.2.44; 990.20), and the salt content by the Volhard method (AOAC, 2000, method number 33.7.1; 935.43). The fat content was determined with the method Gerber (Licitra et al., 2000), and the $\mathrm{pH}$ with a gel filled electrode (model: HA405—DXK—S8/120, Mettler Toledo Process Analytical Inc., Wilmington, MA).

\section{Experimental Design and Statistical Analysis}

The five treatments were: 1) saturated brine at $12^{\circ} \mathrm{C}$ for $24 \mathrm{~d}$; 2) saturated brine at $15^{\circ} \mathrm{C}$ for $24 \mathrm{~d}$; 3) saturated brine at $18^{\circ} \mathrm{C}$ for $24 \mathrm{~d}$; 4) saturated brine at $21^{\circ} \mathrm{C}$ for $24 \mathrm{~d}$; and 5) saturated brine at $24^{\circ} \mathrm{C}$ for $24 \mathrm{~d}$. Cheese manufacture was replicated three times during $3 \mathrm{wk}$ in April. The five treatments were made from the same milk on each day of cheese manufacture. One cheese block was sampled immediately before brine salting and provided data for $0 \mathrm{~d}$ of brining, and other cheese blocks were removed from each brine after $1,4,8,16$, and $24 \mathrm{~d}$ of brine salting, cut into the P1, P2, P3, and P4 portions for each of the five treatments.

Data were analyzed using the GLM procedure of SAS (version 8, 1999, SAS Institute, Cary, NC) using the split-plot model shown in Table 1. Because time of brining was treated as a continuous variable in the ANOVA model, the linear and quadratic terms for time would be correlated. Distortion of the ANOVA by multicolinearity of these terms in the model was minimized by centering the time of brining data using a mathematical transformation (Glantz and Slinker, 2001). The time was transformed as follows: time $=\mathrm{d}$ of brining - [(last testing day - first testing day)/2]. This transformation made the data set orthogonal with respect to time. This transformation directs SAS to determine the effect of brine temperature $(\mathrm{T})$ in the whole plot at the midpoint of time of brining (i.e., d 12) instead of $0 \mathrm{~d}$.

\section{RESULTS}

\section{Total Weight and Moisture Loss and Total Salt and Fat Content During Brining}

All the 3.8-kg blocks lost between 363 to $434 \mathrm{~g}$ in 24 d of brining (Figure 1, Table 2). The weight loss for the $18^{\circ} \mathrm{C}$ brine temperature was similar to the level of weight loss reported in a previous study at $18^{\circ} \mathrm{C}$ for saturated brine (Melilli et al., 2003). There was a significant $(P<0.01)$ impact of the brine temperature on mean weight loss during brining (Table 3 ). The cheeses that were kept in the salt brine at $24^{\circ} \mathrm{C}$ for $24 \mathrm{~d}$ lost more $(P<0.01)$ weight than the cheeses at a lower brine temperature (Table 3 , Figure 1 ). There was a significant linear and quadratic effect of time on weight loss, and a significant interaction of time and brine temperature (Table 3, Figure 1). The cheeses kept in the higher temperature brine for $24 \mathrm{~d}$ had higher least square mean weight loss than cheeses brined at lower temperature (Table 4).

There was a significant effect of brine temperature $(P<0.01)$ on the loss of moisture (Table 3). Moisture loss was higher with increasing brine temperature and was highest at $24^{\circ} \mathrm{C}$ (least square mean $284 \mathrm{~g}$ ) (Table 4, Figure 2). There was a significant linear, quadratic, and time $\times$ temperature effect (Table 3 , Figure 2). Total moisture loss for all the $3.8 \mathrm{-kg}$ blocks was approximately 400 to $500 \mathrm{~g}$ in $24 \mathrm{~d}$ of brining (Figure 2). More than $50 \%$ of the moisture loss occurred during the first $8 \mathrm{~d}$ of brining.

No effect of brine temperature on the total fat content was detected (Table 3). The total salt content was influenced $(P<0.01)$ by the brine temperature (Table 3$)$. 
Table 1. ANOVA model used to determine the effect of temperature and time of brining on salt uptake, moisture loss, and composition changes in the cheese with time of brine salting.

\begin{tabular}{lcll}
\hline Independent variables & $\mathrm{df}$ & Analyzed as & Error term \\
\hline Whole plot & & & \\
$\mathrm{T}^{1}$ & 4 & Category & $\mathrm{T} \times \mathrm{W}$ \\
$\mathrm{W}^{2}$ & 2 & Category & $\mathrm{T} \times \mathrm{W}$ \\
$\mathrm{T} \times \mathrm{W}$ & 8 & Interaction & Model error \\
Subplot & & & \\
$\mathrm{t}^{3}$ & 1 & Continuous & Model error \\
$\mathrm{t} \times \mathrm{T}$ & 4 & Interaction & Model error \\
$\mathrm{t} \times \mathrm{t}$ & 1 & Interaction & Model error \\
$\mathrm{t} \times \mathrm{t} \times \mathrm{T}$ & 4 & Interaction & Model error \\
Error & 65 & & \\
\hline
\end{tabular}

${ }^{1} \mathrm{~T}=$ Temperature of brining.

${ }^{2} \mathrm{~W}=$ Week of cheese making.

${ }^{3} \mathrm{t}=$ Time of brining.

Least square mean total salt content was higher $(P<$ 0.05 ) for the cheeses in the brine at $24^{\circ} \mathrm{C}$ (Table 4). The salt content increased with time as both a linear and quadratic effect (Table 3, Figure 3), and there was an interaction of time and brine temperature $(P \leq 0.01)$ with cheeses brined at lower temperature (e.g., $\left.12^{\circ} \mathrm{C}\right)$ taking longer (ca. $24 \mathrm{~d}$ ) to reach the same content as the cheese brined at the typical temperature of $18^{\circ} \mathrm{C}$ reached in $12 \mathrm{~d}$ (Figure 3 ).

\section{Salt, Fat, and Moisture Concentration in the Cheese During Brining}

The percentage of salt in the cheese was influenced $(P<0.01)$ by brine temperature (Table 3 , Figure 4$)$. The cheeses at the higher brine temperature had a higher percent salt than the cheeses at the lower brine temperature (Table 4$)$. A significant interaction $(P \leq 0.01)$ was found between time and brine temperature (Table 3 , Figure 4) with the difference in salt content due to brine temperature getting larger with longer time in

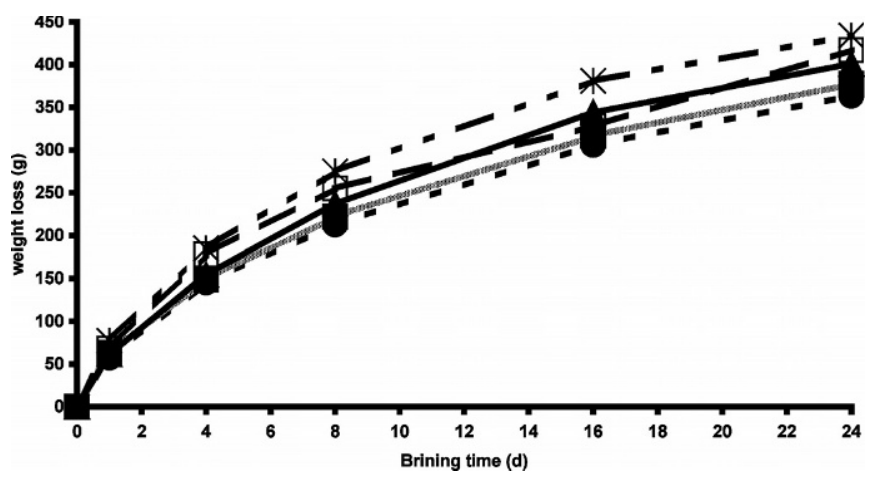

Figure 1. Mean total weight loss (g) per 3.8-kg block. Treatments are brine temperatures of $12(\bullet), 15(\mathbf{\square}), 18(\boldsymbol{\Delta}), 21(\square)$, and $24^{\circ} \mathrm{C}(*)$. the brine. The effect of brine temperature on the percent fat content of cheese was not significant $(P=0.48)$. The fat content of cheeses for all treatments significantly increased with time due to the decrease in moisture content (data not shown).

The percent moisture in the cheese was influenced $(P<0.01)$ by the brine temperature and time of brining (Table 3, Figure 5), with average moisture content of the blocks of cheese for all treatments decreasing by about 9\% during $24 \mathrm{~d}$ of brining (Figure 5). The least square mean percent moisture in the cheese decreased with increased brine temperature (Table 4). Moisture decreased from about 43 to $34 \%$, with more than the $50 \%$ of the decrease in moisture occurring during the first $8 \mathrm{~d}$ (Figure 5). The difference in moisture content of cheese brined at different temperatures got larger (i.e., time $\times$ temperature interaction; Table 3 ) with longer brining time (Figure 5).

\section{Moisture, Salt, $\mathrm{pH}$, and Fat Variation Within Blocks During Brining}

Moisture. Brine temperature had an impact on moisture content of cheese in all portions within the block (Tables 5 and 6 ). In position $\mathrm{P} 1$, the brine at $24^{\circ} \mathrm{C}$ produced cheeses at a lower $(P<0.01)$ moisture (least square mean at $\left.24^{\circ} \mathrm{C}=30.52 \%\right)$ than the brine at the lowest temperature $\left(12^{\circ} \mathrm{C}\right)$ (least square mean at $12^{\circ} \mathrm{C}$ $=32.11 \%$; Figure 6 ). The moisture at the exterior portion of the block (i.e., P1), for all treatments, decreased from about $41 \%$ to about $25 \%$ in $24 \mathrm{~d}$ of brining. Most of the decrease (from 41 to $29 \%$ ) in moisture content of the $\mathrm{P} 1$ position in blocks at the higher brine temperature occurs during the first $4 \mathrm{~d}$ of brining. The cheese held in the brine at $12^{\circ} \mathrm{C}$ did not reach the $29 \%$ moisture in portion $\mathrm{P} 1$ until approximately $12 \mathrm{~d}$ of brining. This would be expected to maintain higher porosity of the exterior portion of the cheese at $12 \mathrm{vs} .24^{\circ} \mathrm{C}$. 
Table 2. Weight in grams, in $24 \mathrm{~d}$ of brining time, for portions P1, P2, P3, and P4 of each treatment: 12 , $15,18,21$, and $24^{\circ} \mathrm{C}$.

\begin{tabular}{|c|c|c|c|c|c|c|}
\hline Days & $\mathrm{P} 1$ & $\mathrm{P} 2$ & P3 & $\mathrm{P} 4$ & $\begin{array}{l}\text { Total } \\
\text { weight }\end{array}$ & $\begin{array}{l}\text { Original } \\
\text { weight }\end{array}$ \\
\hline \multicolumn{7}{|l|}{$12^{\circ} \mathrm{C}$} \\
\hline 0 & 741 & 1093 & 799 & 1158 & 3791 & 3796 \\
\hline 1 & 900 & 1087 & 726 & 995 & 3708 & 3765 \\
\hline 4 & 1003 & 1038 & 707 & 886 & 3635 & 3781 \\
\hline 8 & 1053 & 976 & 661 & 872 & 3562 & 3776 \\
\hline 16 & 1075 & 1007 & 641 & 762 & 3485 & 3794 \\
\hline 24 & 1076 & 1017 & 628 & 685 & 3405 & 3771 \\
\hline \multicolumn{7}{|l|}{$15^{\circ} \mathrm{C}$} \\
\hline 0 & 741 & 1093 & 799 & 1158 & 3791 & 3796 \\
\hline 1 & 863 & 1048 & 765 & 1038 & 3713 & 3778 \\
\hline 4 & 960 & 1019 & 709 & 942 & 3630 & 3780 \\
\hline 8 & 985 & 996 & 681 & 907 & 3570 & 3795 \\
\hline 16 & 1033 & 994 & 643 & 824 & 3494 & 3801 \\
\hline 24 & 1025 & 1005 & 638 & 729 & 3397 & 3777 \\
\hline \multicolumn{7}{|l|}{$18^{\circ} \mathrm{C}$} \\
\hline 0 & 741 & 1093 & 799 & 1158 & 3791 & 3796 \\
\hline 1 & 835 & 1030 & 759 & 1097 & 3721 & 3787 \\
\hline 4 & 929 & 1009 & 703 & 977 & 3618 & 3775 \\
\hline 8 & 955 & 1016 & 671 & 902 & 3545 & 3783 \\
\hline 16 & 981 & 1008 & 642 & 799 & 3430 & 3777 \\
\hline 24 & 903 & 1055 & 646 & 784 & 3387 & 3793 \\
\hline \multicolumn{7}{|l|}{$21^{\circ} \mathrm{C}$} \\
\hline 0 & 741 & 1093 & 799 & 1158 & 3791 & 3796 \\
\hline 1 & 826 & 1041 & 743 & 1062 & 3671 & 3743 \\
\hline 4 & 921 & 989 & 691 & 970 & 3571 & 3752 \\
\hline 8 & 958 & 988 & 669 & 914 & 3529 & 3786 \\
\hline 16 & 865 & 1048 & 661 & 858 & 3431 & 3783 \\
\hline 24 & 879 & 1050 & 663 & 743 & 3335 & 3755 \\
\hline \multicolumn{7}{|l|}{$24^{\circ} \mathrm{C}$} \\
\hline 0 & 741 & 1093 & 799 & 1158 & 3791 & 3796 \\
\hline 1 & 819 & 1044 & 760 & 1073 & 3697 & 3777 \\
\hline 4 & 935 & 987 & 680 & 957 & 3559 & 3747 \\
\hline 8 & 971 & 1004 & 656 & 871 & 3502 & 3779 \\
\hline 16 & 811 & 1119 & 681 & 777 & 3389 & 3775 \\
\hline 24 & 941 & 1061 & 671 & 662 & 3335 & 3775 \\
\hline
\end{tabular}

The cheese in portion P2 (Figure 7) also decreased in moisture with time of brining, but the change with time was more linear than quadratic compared with P1 (Table 6). There was a significant $(P \leq 0.01)$ linear and quadratic interaction of time $\times$ brining temperature in portion P2 (Table 6), with the 24-d-old cheeses at $24^{\circ} \mathrm{C}$ brine temperature having a lower moisture content (approximately 32\%) than the cheeses held in the $12^{\circ} \mathrm{C}$ brine (approximately $35 \%$ ). The cheese in portion P3 (Figure 8) showed a significant $(P<0.01)$ linear effect of time and a significant $(P<0.01)$ interaction time $\times$ brine temperature with the cheese at higher brine temperature having lower moisture (Table 6, Figure 8). In the portion $\mathrm{P} 4$, a significant linear and quadratic effect of the time $(P<0.01)$ and a significant interaction of time $\times$ brine temperature were detected (Table 6, Figure 9). The final moisture content in the P4 portion decreased during $24 \mathrm{~d}$ from 43 to $42 \%$ for the cheese held at $12^{\circ} \mathrm{C}$ and from 43 to $40 \%$ for cheese held in $24^{\circ} \mathrm{C}$ brine.
Salt. There was a significant $(P \leq 0.01)$ impact of brine temperature on salt content for all the portions (Tables 7 and 8). In general, the salt content of the cheese in all four portions for cheese held at the higher brine temperature was higher than for the cheese held at lower brine temperature (Figures 10 to 13). Linear and quadratic effects $(P \leq 0.01)$ of brining time were detected for all portions of the blocks (Table 8). The P1 portion of cheese kept in $24^{\circ} \mathrm{C}$ brine had a higher $(P<$ 0.05 ) salt content (least square mean $=3 \%$ ) than the $\mathrm{P} 1$ portion of cheese kept at $12^{\circ} \mathrm{C}$ (least square mean $=2.7 \%$ ). There was an interaction effect of the linear term for time $\times$ brine temperature $(P \leq 0.01)$ in portions P2, P3, and P4 (Table 8) on salt content, with cheeses brined at higher temperature increasing faster in salt content with time. The cheese in portions P2 showed an interaction of brine temperature by the quadratic effect (Table 8, Figure 11) of time $(P<0.01)$.

pH and fat content. The $\mathrm{pH}$ for all cheeses (Table 4) and for all the portions (data not shown) was in the 
Table 3. Type III sum of the squares and probability values (in parentheses) for the ANOVA analysis of the impact of brine temperature (T) and time $(\mathrm{t})$ of brining on the total weight loss, the total salt content, the total moisture loss, the total fat content, the percentage of salt, moisture, and fat content of a $15 \times 15 \times 15 \mathrm{~cm}$ block of Ragusano cheese.

\begin{tabular}{|c|c|c|c|c|c|c|c|c|}
\hline Factors & $\mathrm{df}$ & $\begin{array}{l}\text { Total } \\
\text { weight } \\
\text { loss (g) }\end{array}$ & $\begin{array}{l}\text { Total } \\
\text { moisture } \\
\text { loss (g) }\end{array}$ & $\begin{array}{l}\text { Total } \\
\text { fat } \\
\text { content } \\
\text { (g) }\end{array}$ & $\begin{array}{l}\text { Total } \\
\text { salt } \\
\text { content } \\
\text { (g) }\end{array}$ & $\begin{array}{l}\text { Salt } \\
\text { content } \\
(\%)\end{array}$ & $\begin{array}{l}\text { Fat } \\
\text { content } \\
(\%)\end{array}$ & $\begin{array}{l}\text { Moisture } \\
\text { content } \\
(\%)\end{array}$ \\
\hline $\mathrm{W}^{2}$ & 2 & $\begin{array}{l}12,611^{*} \\
(<0.01)\end{array}$ & $\begin{array}{l}18,071^{*} \\
(<0.01)\end{array}$ & $\begin{array}{l}27,347^{*} \\
(<0.01)\end{array}$ & $\begin{array}{l}639 * \\
(<0.01)\end{array}$ & $\begin{array}{c}0.478^{*} \\
(<0.01)\end{array}$ & $\begin{array}{l}16.598^{*} \\
(0.01)\end{array}$ & $\begin{array}{l}33.107^{*} \\
(<0.01)\end{array}$ \\
\hline$\underset{t^{3}}{\text { Subplot }}$ & 1 & $\begin{array}{r}1,550,344^{*} \\
(<0.01)\end{array}$ & $\begin{array}{r}2,423,040^{*} \\
(<0.01)\end{array}$ & $\begin{array}{l}1416 \\
\quad(0.21)\end{array}$ & $\begin{array}{l}97,022^{*} \\
\quad(<0.01)\end{array}$ & $\begin{array}{l}87.441^{*} \\
(<0.01)\end{array}$ & $\begin{array}{l}112.938^{*} \\
(<0.01)\end{array}$ & $\begin{array}{l}825.806^{*} \\
(<0.01)\end{array}$ \\
\hline $\mathrm{t} \times \mathrm{T}$ & 4 & $\begin{array}{l}5810^{*} \\
(0.02)\end{array}$ & $\begin{array}{l}8143^{*} \\
(0.03)\end{array}$ & $\begin{array}{l}1588 \\
\quad(0.77)\end{array}$ & $\begin{array}{l}447^{*} \\
\quad(0.01)\end{array}$ & $\begin{array}{l}0.473^{*} \\
(0.01)\end{array}$ & $\begin{array}{c}0.724 \\
(0.92)\end{array}$ & $\begin{array}{l}3.768^{*} \\
(0.04)\end{array}$ \\
\hline $\begin{array}{l}\text { Total SS } \\
\text { Error } \\
\mathrm{R}^{2}\end{array}$ & $\begin{array}{l}89 \\
65\end{array}$ & $\begin{array}{r}1,850,866 \\
30,870 \\
0.98\end{array}$ & $\begin{array}{r}2,886,007 \\
47,915 \\
0.98\end{array}$ & $\begin{array}{r}104,091 \\
56,997 \\
0.45\end{array}$ & $\begin{array}{c}115,722 \\
2203 \\
0.98\end{array}$ & $\begin{array}{c}102.080 \\
1.604 \\
0.98\end{array}$ & $\begin{array}{c}201.278 \\
52.034 \\
0.74\end{array}$ & $\begin{array}{c}1007.096 \\
23.276 \\
0.98\end{array}$ \\
\hline
\end{tabular}

*Statistically significant.

${ }^{1} \mathrm{~T}=$ Temperature of brining.

${ }^{2} \mathrm{~W}=$ Week of cheese making.

${ }^{3} \mathrm{t}=$ Time of brining.

range of 5.28 to 5.29 and there was no consistent impact of brine temperature observed. In general, the fat content of the $\mathrm{P} 1, \mathrm{P} 2$, and $\mathrm{P} 3$ portions increased $(P<0.01)$ with time (Table 9 ) due to the decrease (Table 6 , Figures 6 to 9) in moisture with time. The impact of brining time on fat content was the largest (an increase in fat content from about 25 to $31.8 \%$ ) at the exterior of the cheese (P1) where the moisture decrease during $24 \mathrm{~d}$ of brining was the largest. In the center of cheese (P4) the fat content remained almost constant during the $24 \mathrm{~d}$ of brining at about $25.2 \%$. A significant $(P=0.02)$ impact of the brine temperature on fat content was only detected in portion P2 (Table 9) but the magnitude of the impact was small (approximately 1.1\%).

\section{DISCUSSION}

\section{Factors Influencing Salt Uptake and Moisture Loss During Brining}

When salt penetrates cheese, during brine salting, there is a movement of water out the block of cheese into

Table 4. Least square means for ANOVA to determine the impact of brine temperature on weight loss, salt, fat, moisture (content and percent), and $\mathrm{pH}$.

\begin{tabular}{lccccc}
\hline & \multicolumn{5}{c}{ Temperature of brine } \\
\cline { 2 - 6 } Dependent variables & $12^{\circ} \mathrm{C}$ & $15^{\circ} \mathrm{C}$ & $18^{\circ} \mathrm{C}$ & $21^{\circ} \mathrm{C}$ & $24^{\circ} \mathrm{C}$ \\
\hline Total weight loss (g) & $181^{\mathrm{d}}$ & $188^{\mathrm{b}, \mathrm{c}, \mathrm{d}}$ & $200^{\mathrm{b}}$ & $211^{\mathrm{b}}$ & $225^{\mathrm{a}}$ \\
Total salt content (g) & $48^{\mathrm{c}}$ & $48^{\mathrm{c}}$ & $52^{\mathrm{b}}$ & $52^{\mathrm{b}}$ & $59^{\mathrm{a}}$ \\
Total moisture loss (g) & $29^{\mathrm{c}}$ & $233^{\mathrm{c}}$ & $252^{\mathrm{b}}$ & $263^{\mathrm{b}}$ & $284^{\mathrm{a}}$ \\
Total fat content (g) & 951 & 974 & 961 & 943 & 950 \\
Salt (\%) & $1.37^{\mathrm{c}}$ & $1.28^{\mathrm{c}}$ & $1.51^{\mathrm{b}}$ & $1.51^{\mathrm{b}}$ & $1.71^{\mathrm{a}}$ \\
Moisture (\%) & $38.87^{\mathrm{a}}$ & $38.72^{\mathrm{a}}$ & $38.29^{\mathrm{b}}$ & $38.04^{\mathrm{b}}$ & $37.61^{\mathrm{c}}$ \\
Fat (\%) & 26.50 & 27.11 & 26.87 & 26.59 & 26.87 \\
pH & 5.29 & 5.29 & 5.28 & 5.28 & 5.28 \\
\hline \multicolumn{2}{c}{ a,b,c,d Least square means that do not share a common superscript are different at $P<0.05$ level. }
\end{tabular}




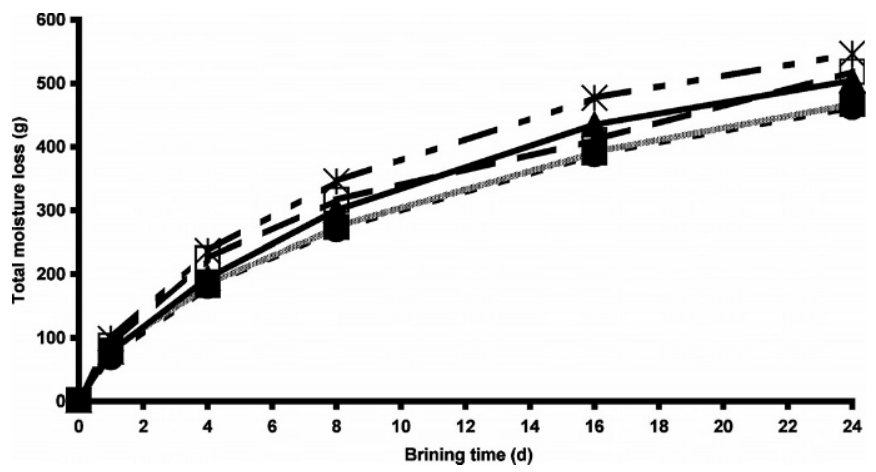

Figure 2. Mean total moisture loss (g) per 3.8-kg block. Treatments are brine temperatures of $12(\bullet), 15(\mathbf{\square}), 18(\boldsymbol{\Delta}), 21(\square)$, and $24^{\circ} \mathrm{C}(*)$.

the brine (Geurts et al., 1974). Generally, the weight of water expelled from the block is larger than the weight of salt taken up. Prediction of the rate of penetration of salt into cheese during brine salting (i.e., diffusion coefficient) has been mathematically modeled by many investigators (Geurts et al., 1974, 1980; Guinee and Fox, 1983; Luna and Chavez, 1992; Payne and Morison, 1999; Turhan and Gunasekaran, 1999). Factors within a block of cheese that influence the rate at which salt can move from the exterior surface to the center of the block are: porosity of the cheese, tortuosity of the channels of water within the structure of the cheese, proportion of water that is bound in cheese, viscosity of the free water portion of the cheese, and interaction of sodium with the protein matrix. The porosity of cheese is influenced by its moisture content. In two cheeses of same type, the cheese with higher moisture content absorbs salt more rapidly (Geurts et al., 1974), because it has higher porosity. Salt travels from the exterior surface to the center of a block of cheese within the water phase of the cheese. Salt cannot travel through the protein matrix or the fat phase of cheese.

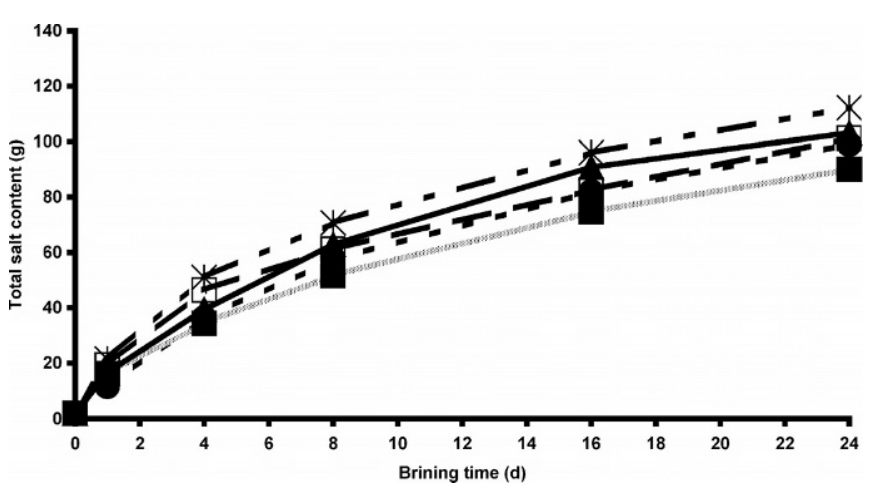

Figure 3. Mean total salt content (g) per 3.8-kg block. Treatments are brine temperatures of $12(\bullet), 15(\mathbf{\square}), 18(\boldsymbol{\Delta}), 21(\square)$, and $24^{\circ} \mathrm{C}(*)$.

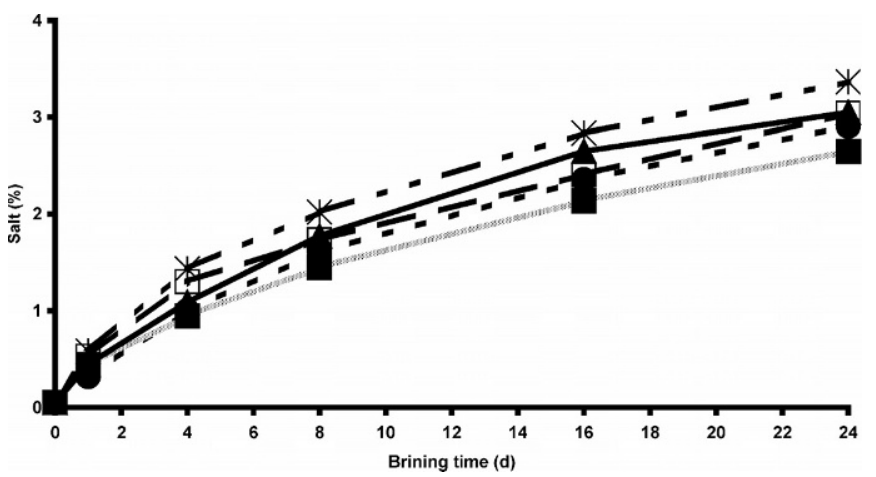

Figure 4. Mean salt concentration (\%) per 3.8-kg block. Treat-

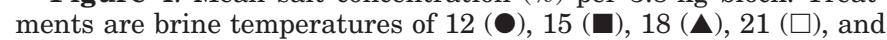
$24^{\circ} \mathrm{C}(*)$.

Thus, a cheese with a higher moisture content has a structure that is more porous and has less tortuosity of the water channels within the structure. The higher the degree of tortuosity of the channels of water within structure of a block of cheese, the more slowly salt will penetrate the block (Geurts et al., 1974).

Brine concentration and presalting. Resmini et al. (1974) found that salt uptake was faster when a nonsaturated brine (approximately 16\%) was used for the first 5 to $6 \mathrm{~d}$ of brining followed by a saturated brine until $24 \mathrm{~d}$. This was confirmed by Melilli et al. (2003) in a study of the impact of brine concentration (18\% vs. saturated brine) and presalting on the rate of salt penetration in Ragusano cheese at $18^{\circ} \mathrm{C}$. The blocks of cheese were segmented into four portions $\mathrm{P} 1$ to $\mathrm{P} 4$, with the exterior portion as $\mathrm{P} 1$ and the interior portion as P4 (Melilli et al., 2003). The cheeses in saturated brine rapidly decreased in porosity near the surface (P1) of the block because of the higher moisture loss from the P1 portion that occurred during the first $4 \mathrm{~d}$. This change in structure of the cheese in the $\mathrm{P} 1$ portion

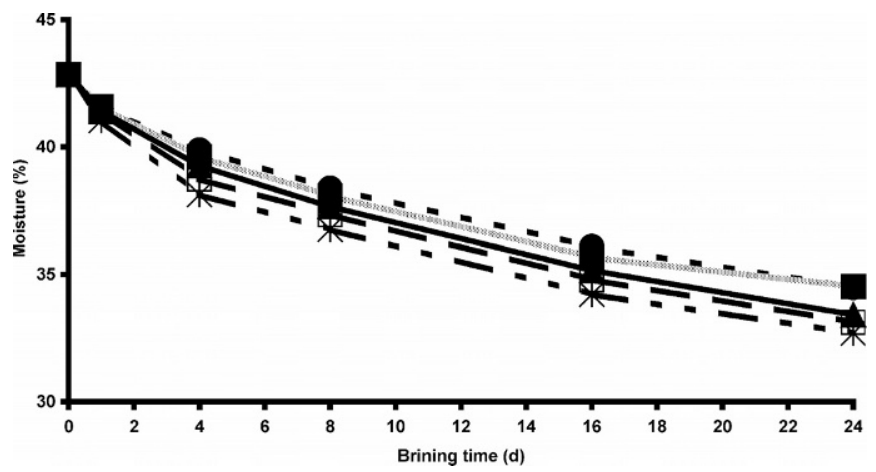

Figure 5. Mean moisture concentration (\%) per 3.8-kg block. Treatments are brine temperatures of $12(\bullet), 15(\square), 18(\boldsymbol{\Lambda}), 21(\square)$, and $24^{\circ} \mathrm{C}(*)$. 
Table 5. Percent moisture content, in $24 \mathrm{~d}$ of brining time, for portions P1, P2, P3, and P4 for each treatment: $12,15,18,21$, and $24^{\circ} \mathrm{C}$.

\begin{tabular}{|c|c|c|c|c|}
\hline Days & $\mathrm{P} 1$ & P2 & P3 & $\mathrm{P} 4$ \\
\hline \multicolumn{5}{|l|}{$12^{\circ} \mathrm{C}$} \\
\hline 0 & 40.69 & 43.43 & 43.28 & 43.35 \\
\hline 1 & 36.29 & 43.03 & 43.32 & 43.40 \\
\hline 4 & 32.26 & 41.52 & 43.34 & 43.82 \\
\hline 8 & 30.16 & 39.94 & 42.39 & 43.45 \\
\hline 16 & 27.32 & 37.29 & 40.67 & 43.01 \\
\hline 24 & 25.92 & 35.08 & 39.72 & 42.26 \\
\hline \multicolumn{5}{|l|}{$15^{\circ} \mathrm{C}$} \\
\hline 0 & 40.69 & 43.43 & 43.28 & 43.35 \\
\hline 1 & 35.86 & 42.96 & 43.44 & 43.54 \\
\hline 4 & 31.64 & 41.32 & 42.84 & 43.46 \\
\hline 8 & 29.48 & 39.36 & 41.86 & 43.15 \\
\hline 16 & 26.19 & 36.75 & 40.31 & 42.59 \\
\hline 24 & 25.33 & 35.47 & 39.21 & 42.03 \\
\hline \multicolumn{5}{|l|}{$18^{\circ} \mathrm{C}$} \\
\hline 0 & 40.69 & 43.43 & 43.28 & 43.35 \\
\hline 1 & 35.61 & 42.73 & 43.21 & 43.36 \\
\hline 4 & 31.19 & 40.66 & 42.45 & 43.16 \\
\hline 8 & 28.82 & 38.38 & 41.26 & 43.49 \\
\hline 16 & 25.94 & 35.58 & 39.43 & 42.43 \\
\hline 24 & 24.21 & 33.29 & 37.78 & 40.64 \\
\hline \multicolumn{5}{|l|}{$21^{\circ} \mathrm{C}$} \\
\hline 0 & 40.69 & 43.43 & 43.28 & 43.35 \\
\hline 1 & 35.30 & 42.71 & 43.41 & 43.41 \\
\hline 4 & 29.95 & 40.12 & 42.08 & 43.30 \\
\hline 8 & 28.01 & 38.18 & 41.53 & 43.15 \\
\hline 16 & 24.79 & 34.76 & 38.83 & 41.77 \\
\hline 24 & 23.82 & 33.12 & 37.22 & 40.53 \\
\hline \multicolumn{5}{|l|}{$24^{\circ} \mathrm{C}$} \\
\hline 0 & 40.69 & 43.43 & 43.28 & 43.35 \\
\hline 1 & 34.70 & 42.14 & 43.13 & 43.33 \\
\hline 4 & 29.35 & 39.13 & 41.89 & 43.00 \\
\hline 8 & 27.80 & 37.52 & 40.65 & 42.92 \\
\hline 16 & 25.29 & 33.42 & 38.09 & 41.28 \\
\hline 24 & 25.30 & 32.42 & 36.31 & 39.91 \\
\hline
\end{tabular}

created a larger barrier to entrance of salt from the saturated brine than for cheese in $18 \%$ brine. The use of $18 \%$ brine during the first $8 \mathrm{~d}$ of brining (instead of saturated brine) created less of barrier to salt and moisture movement through portion P1 (i.e., exterior surface) and allowed more rapid penetration of salt into the block and more total salt uptake. Therefore, the use of $18 \%$ brine delayed the shrinkage and moisture loss from of the exterior portion of the block and the development of a barrier to salt and moisture movement. Shrinkage (due to moisture loss) of the exterior portion of the block would also increase the tortuosity in portion $\mathrm{P} 1$. Presalting of the cheese before brine salting in saturated or $18 \%$ brine did not influence the rate of penetration of salt. These results are consistent with the idea of formation of a barrier (i.e., decreased porosity) to moisture and salt migration at the surface of the block, as proposed by Resmini et al. (1974), and higher salt concentration in brine makes this barrier form more rapidly and decreases the rate of salt uptake.
Brine temperature. In a study of salt diffusion in White cheese during brining by Turhan and Kaletunç (1992), it was reported that brine temperature (i.e., $4,12.5$, and $20^{\circ} \mathrm{C}$ ), had a significant impact on salt penetration with slower salt penetration at lower temperature because salt diffusivity decreased with decreasing temperature.

In the present study, salt uptake decreased with decreasing brine temperature (Figure 4, Table 3). However, moisture loss also decreased with decreasing brine temperature (Figure 2, Table 3), which would produce a cheese with higher porosity. In a previous study (Melilli et al., 2003) of the impact of brine concentration on salt uptake and moisture loss at $18^{\circ} \mathrm{C}$, it was found that lower brine concentration ( $18 \%$ vs. saturated brine) reduced moisture loss from the exterior surface of the cheese, kept the surface more porous, and allowed more salt uptake. Based on the results of the previous study, higher porosity with decreasing brine temperature would be expected to increase the rate of salt penetra- 
Table 6. Type III sum of the squares and probability values (in parentheses) for the ANOVA analysis of the impact of brine temperature $(\mathrm{T})$ and time $(\mathrm{t})$ of brining on moisture content of cheese portions $\mathrm{P} 1, \mathrm{P} 2$, P3, and P4 within a $15 \times 15 \times 15 \mathrm{~cm}$ block of Ragusano cheese.

\begin{tabular}{|c|c|c|c|c|c|}
\hline Factors & $\mathrm{df}$ & $\mathrm{P} 1$ & $\mathrm{P} 2$ & P3 & $\mathrm{P} 4$ \\
\hline $\begin{array}{l}\text { Whole plot } \\
\mathrm{T}^{1}\end{array}$ & 4 & $\begin{array}{c}29.71^{*} \\
(<0.01)\end{array}$ & $\begin{array}{c}42.37^{*} \\
(<0.01)\end{array}$ & $\begin{array}{c}17.70^{*} \\
(<0.01)\end{array}$ & $\begin{array}{c}4.80^{*} \\
(0.01)\end{array}$ \\
\hline $\mathrm{W}^{2}$ & 2 & $\begin{array}{l}10.94 \\
(0.22)\end{array}$ & $\begin{array}{c}22.67^{*} \\
(<0.01)\end{array}$ & $\begin{array}{c}42.81^{*} \\
(<0.01)\end{array}$ & $\begin{array}{l}45.46^{*} \\
(<0.01)\end{array}$ \\
\hline $\mathrm{T} \times \mathrm{W}$ & 8 & $\begin{array}{c}1.25 \\
(1.00)\end{array}$ & $\begin{array}{c}1.71 \\
(0.80)\end{array}$ & $\begin{array}{c}1.27 \\
(0.81)\end{array}$ & $\begin{array}{l}1.24 \\
(0.44)\end{array}$ \\
\hline Subplot & 1 & $\begin{array}{r}1890.00^{*} \\
(<0.01)\end{array}$ & $\begin{array}{c}1022.57^{*} \\
(<0.01)\end{array}$ & $\begin{array}{c}344.20^{*} \\
(<0.01)\end{array}$ & $\begin{array}{c}64.65^{*} \\
(<0.01)\end{array}$ \\
\hline $\mathrm{t} \times \mathrm{T}$ & 4 & $\begin{array}{c}5.91 \\
(0.79)\end{array}$ & $\begin{array}{c}13.01^{*} \\
(<0.01)\end{array}$ & $\underset{(<0.01)}{16.41^{*}}$ & $\begin{array}{r}8.98^{*} \\
(<0.01)\end{array}$ \\
\hline $\mathrm{t} \times \mathrm{t}$ & 1 & $\begin{array}{c}458.54^{*} \\
(<0.01)\end{array}$ & $\begin{array}{c}41.40^{*} \\
(<0.01)\end{array}$ & $\begin{array}{c}0.57 \\
(0.16)\end{array}$ & $\begin{array}{r}4.32^{*} \\
(<0.01)\end{array}$ \\
\hline $\mathrm{t} \times \mathrm{t} \times \mathrm{T}$ & 4 & $\begin{array}{c}7.41 \\
(0.72)\end{array}$ & $\begin{array}{l}6.08^{*} \\
(0.01)\end{array}$ & $\begin{array}{c}0.52 \\
(0.77)\end{array}$ & $\begin{array}{c}0.97 \\
(0.19)\end{array}$ \\
\hline $\begin{array}{l}\text { Total SS } \\
\text { Error } \\
\mathrm{R}^{2}\end{array}$ & $\begin{array}{l}89 \\
65\end{array}$ & $\begin{array}{r}2816.53 \\
228.76 \\
0.92\end{array}$ & $\begin{array}{r}1227.64 \\
24.29 \\
0.98\end{array}$ & $\begin{array}{r}457.78 \\
18.67 \\
0.96\end{array}$ & $\begin{array}{r}142.51 \\
10.00 \\
0.93\end{array}$ \\
\hline
\end{tabular}

*Statistically significant.

${ }^{1} \mathrm{~T}=$ temperature of brining.

${ }^{2} \mathrm{~W}$ = week of cheese making.

${ }^{3} \mathrm{t}=$ time of brining.

tion into the cheese; however, the opposite result (Figure 4, Table 3) was observed in the present study. This would indicate that low brine temperature $\left(12^{\circ} \mathrm{C}\right)$, and the increased viscosity of the aqueous phase of the cheese at lower brine temperature (i.e., 12 vs. $24^{\circ} \mathrm{C}$ ), had a larger influence on reducing salt penetration, than the impact of increased porosity of the cheese at $12{ }^{\circ} \mathrm{C}$.

\section{Influence of Temperature and Salt on the Water Phase of Cheese}

The viscosity of milk and the water phase of cheese is higher than pure water. Increased milk protein con-

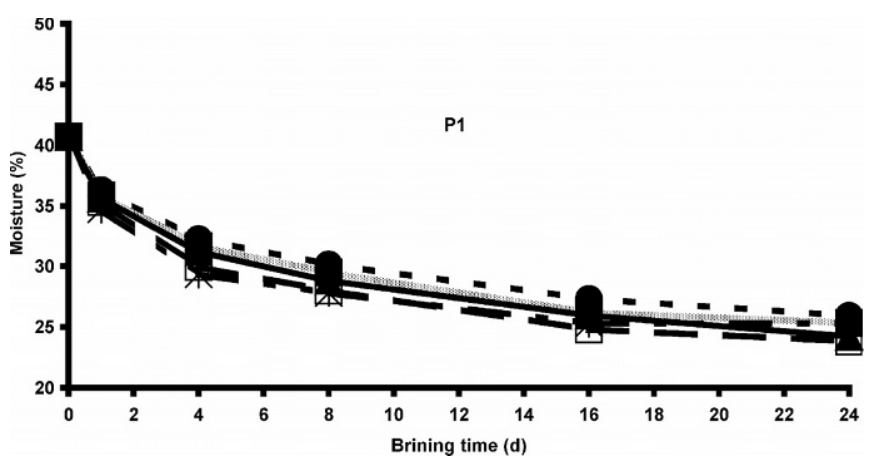

Figure 6. Mean moisture (\%) in the P1 portion of the block. Treat-

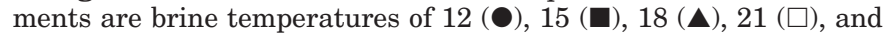
$24^{\circ} \mathrm{C}(*)$. centration in fluid milks caused viscosity to increase (Quiñones et al., 1997, 1998). The difference in viscosity is caused by dissolved substances and dispersed particles (Walstra et al., 1999). The water phase of the cheese contains dissolved minerals, lactose, lactic acid, intact proteins, and proteolysis products. Guo et al. (1997) reported that the protein content of the expressible serum from Mozzarella cheese increased with time of storage and salt content from about $3 \% \mathrm{CP}$ to nearly $10 \%$ $\mathrm{CP}$ over a period of $10 \mathrm{~d}$ after manufacturing at $4^{\circ} \mathrm{C}$. Unsalted cheese had a low concentration of protein in the water phase and maintained a higher expressible

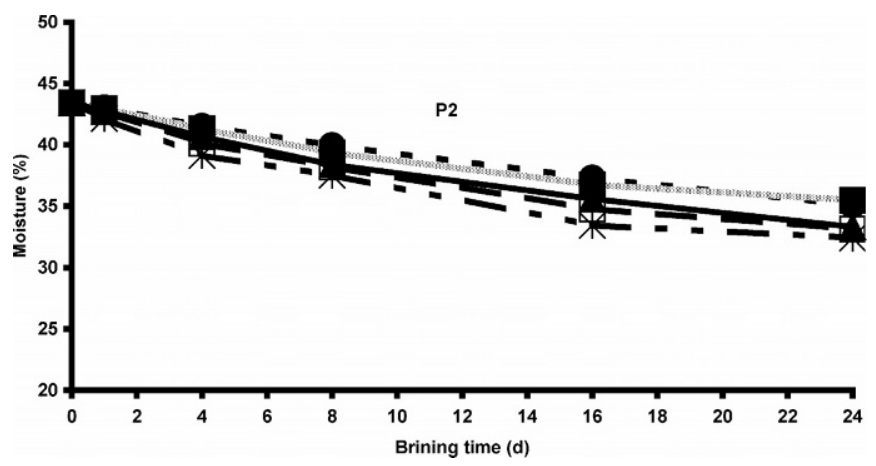

Figure 7. Mean moisture (\%) in the P2 portion of the block. Treatments are brine temperatures of $12(\bullet), 15(\mathbb{\square}), 18(\mathbf{\Lambda}), 21(\square)$, and $24^{\circ} \mathrm{C}(*)$. 


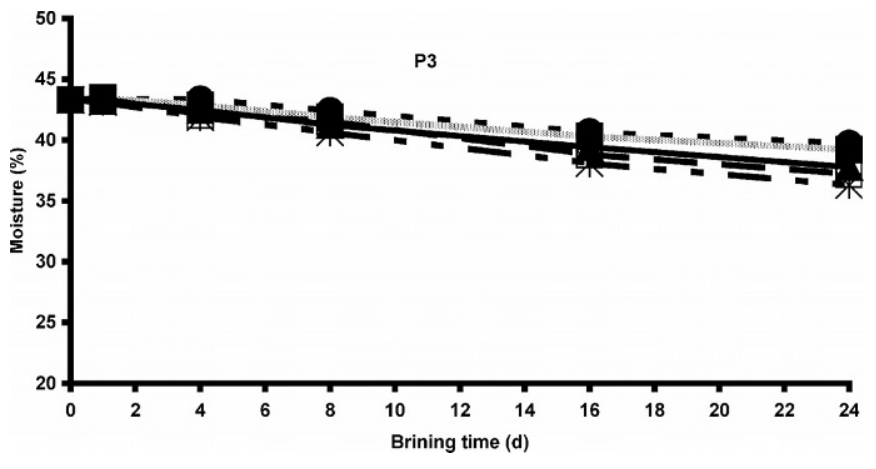

Figure 8. Mean moisture (\%) in the P3 portion of the block. Treatments are brine temperatures of $12(\bullet), 15(\square), 18(\boldsymbol{\Delta}), 21(\square)$, and $24^{\circ} \mathrm{C}(*)$.

serum during $10 \mathrm{~d}$ at $4^{\circ} \mathrm{C}$ than salted cheese (Guo et al., 1997). Increases in protein concentration and concentration of calcium in the water phase of cheese could cause a large increase in the viscosity of the water phase and would be expected to increase the difficulty of removal of expressible serum from the cheese under constant temperature and g-force, as reported by Guo et al. (1997). The viscosity of milk is temperature dependent, and lower temperature favors higher viscosity (Walstra et al., 1999). The viscosity of the water phase would be temperature dependent, with lower brining temperatures favoring higher viscosity (Payne and Morison, 1999 ) and slower salt penetration (Turhan and Kaletunç, 1992). Guo and Kindstedt (1995) reported that at temperatures less than $20^{\circ} \mathrm{C}$, it was difficult to remove expressible serum from the cheese.

Before transfer of the blocks of cheese into the brine in the present study, they were all at $18^{\circ} \mathrm{C}$. For the blocks placed into the $12^{\circ} \mathrm{C}$ brine, the temperature of cheese decreased throughout the block before any significant salt penetration occurred. The decrease in temperature would cause some movement of caseins (par-

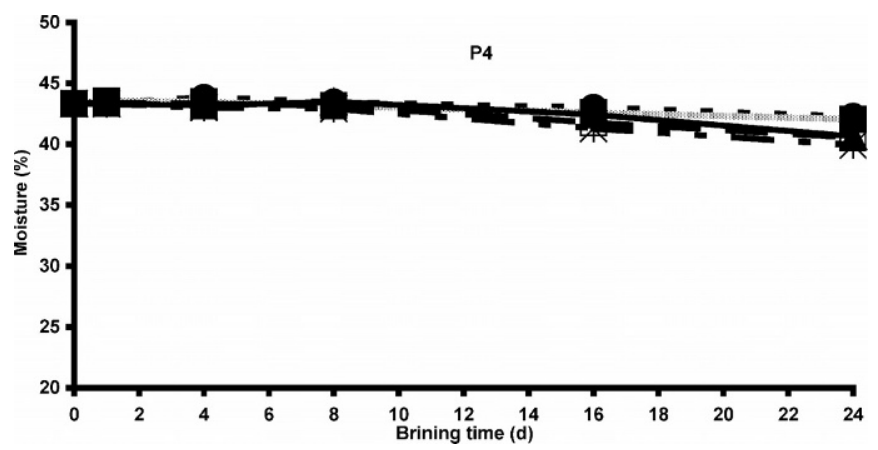

Figure 9. Mean moisture (\%) in the P4 portion of the block. Treatments are brine temperatures of $12(\bullet), 15(\square), 18(\mathbf{\Delta}), 21(\square)$, and $24^{\circ} \mathrm{C}(*)$.
Table 7. Percent salt content, in $24 \mathrm{~d}$ of brining time, for portions P1, P2, P3, and P4 for each treatment: $12,15,18,21$, and $24^{\circ} \mathrm{C}$.

\begin{tabular}{|c|c|c|c|c|}
\hline Days & $\mathrm{P} 1$ & $\mathrm{P} 2$ & P3 & $\mathrm{P} 4$ \\
\hline \multicolumn{5}{|l|}{$12^{\circ} \mathrm{C}$} \\
\hline 0 & 0.07 & 0.05 & 0.05 & 0.04 \\
\hline 1 & 1.05 & 0.12 & 0.06 & 0.04 \\
\hline 4 & 2.68 & 0.79 & 0.11 & 0.04 \\
\hline 8 & 3.46 & 1.53 & 0.65 & 0.19 \\
\hline 16 & 4.22 & 2.50 & 1.30 & 0.42 \\
\hline 24 & 4.57 & 3.21 & 1.85 & 0.84 \\
\hline \multicolumn{5}{|l|}{$15^{\circ} \mathrm{C}$} \\
\hline 0 & 0.07 & 0.05 & 0.05 & 0.04 \\
\hline 1 & 1.56 & 0.20 & 0.06 & 0.03 \\
\hline 4 & 2.57 & 0.76 & 0.22 & 0.04 \\
\hline 8 & 3.07 & 1.54 & 0.69 & 0.15 \\
\hline 16 & 3.74 & 2.37 & 1.32 & 0.48 \\
\hline 24 & 4.04 & 2.93 & 1.92 & 0.95 \\
\hline \multicolumn{5}{|l|}{$18^{\circ} \mathrm{C}$} \\
\hline 0 & 0.07 & 0.05 & 0.05 & 0.04 \\
\hline 1 & 1.63 & 0.21 & 0.04 & 0.04 \\
\hline 4 & 2.85 & 1.01 & 0.33 & 0.04 \\
\hline 8 & 3.66 & 1.96 & 0.97 & 0.16 \\
\hline 16 & 4.36 & 3.05 & 1.82 & 0.69 \\
\hline 24 & 4.49 & 3.54 & 2.41 & 1.24 \\
\hline \multicolumn{5}{|l|}{$21^{\circ} \mathrm{C}$} \\
\hline 0 & 0.07 & 0.05 & 0.05 & 0.04 \\
\hline 1 & 1.81 & 0.30 & 0.07 & 0.06 \\
\hline 4 & 3.19 & 1.28 & 0.50 & 0.10 \\
\hline 8 & 3.38 & 2.04 & 0.91 & 0.28 \\
\hline 16 & 3.94 & 2.90 & 1.82 & 0.71 \\
\hline 24 & 4.34 & 3.42 & 2.53 & 1.41 \\
\hline \multicolumn{5}{|l|}{$24^{\circ} \mathrm{C}$} \\
\hline 0 & 0.07 & 0.05 & 0.05 & 0.04 \\
\hline 1 & 1.99 & 0.39 & 0.08 & 0.05 \\
\hline 4 & 3.32 & 1.52 & 0.52 & 0.14 \\
\hline 8 & 3.76 & 2.24 & 1.31 & 0.36 \\
\hline 16 & 4.36 & 3.43 & 2.21 & 0.93 \\
\hline 24 & 4.58 & 3.73 & 2.88 & 1.53 \\
\hline
\end{tabular}

ticularly $\beta$-casein) from the casein matrix into the water phase of the cheese due to decreased hydrophobic interactions (Payens, 1979). Movement of $\beta$-casein from micelles into the serum phase of milk with decreased temperature causes an increase in viscosity (Walstra et al., 1999). As salt starts to enter the cheese through the porous structure of the $\mathrm{P} 1$ portion, the increasing salt in the water channels would be expected to cause transfer of caseins from the matrix into the water phase of the cheese, as observed by Guo et al. (1997). This additional increase in casein concentration in the water phase of cheese near the exterior, in combination with low temperature (e.g., $12^{\circ} \mathrm{C}$ ), would be expected to further reduce the rate of salt penetration and moisture loss due to an increase in viscosity of the water phase compared with cheese at $24^{\circ} \mathrm{C}$.

At the same time, the moisture content of the exterior P1 portion of the block was decreasing rapidly (Figure 6 ) and this caused the porosity of the exterior surface of the cheese to decrease at all brine temperatures. This decrease in porosity coupled with the decrease in 
Table 8. Type III sum of the squares and probability values (in parentheses) for the ANOVA analysis of the impact of brine temperature $(\mathrm{T})$ and time $(\mathrm{t})$ of brining on salt content of cheese portions $\mathrm{P} 1, \mathrm{P} 2, \mathrm{P} 3$, and P4 within a $15 \times 15 \times 15 \mathrm{~cm}$ block of Ragusano cheese.

\begin{tabular}{|c|c|c|c|c|c|}
\hline Factors & $\mathrm{df}$ & $\mathrm{P} 1$ & $\mathrm{P} 2$ & P3 & $\mathrm{P} 4$ \\
\hline $\begin{array}{l}\text { Whole plot } \\
\mathrm{T}^{1}\end{array}$ & 4 & $\begin{array}{l}1.89 * \\
(0.01)\end{array}$ & $\begin{array}{c}3.82^{*} \\
(<0.01)\end{array}$ & $\begin{array}{r}2.46^{*} \\
(<0.01)\end{array}$ & $\begin{array}{c}0.42^{*} \\
(0.01)\end{array}$ \\
\hline $\mathrm{W}^{2}$ & 2 & $\begin{array}{l}1.12 \\
(0.21)\end{array}$ & $\underset{(<0.01)}{1.03^{*}}$ & $\begin{array}{r}0.62^{*} \\
(<0.01)\end{array}$ & $\begin{array}{r}0.23^{*} \\
(<0.01)\end{array}$ \\
\hline $\mathrm{T} \times \mathrm{W}$ & 8 & $\begin{array}{c}0.34 \\
(0.99)\end{array}$ & $\begin{array}{c}0.13 \\
(0.67)\end{array}$ & $\begin{array}{c}0.09 \\
(0.84)\end{array}$ & $\begin{array}{c}0.05 \\
(0.23)\end{array}$ \\
\hline$\underset{t^{3}}{\text { Subplot }}$ & 1 & $\begin{array}{c}133.85^{*} \\
(<0.01)\end{array}$ & $\begin{array}{l}125.07^{*} \\
(<0.01)\end{array}$ & $\begin{array}{c}64.26^{*} \\
(<0.01)\end{array}$ & $\begin{array}{c}15.95^{*} \\
(<0.01)\end{array}$ \\
\hline $\mathrm{t} \times \mathrm{T}$ & 4 & $\begin{array}{c}0.91 \\
(0.63)\end{array}$ & $\begin{array}{c}0.73^{*} \\
(<0.01)\end{array}$ & $\begin{array}{c}1.73^{*} \\
(<0.01)\end{array}$ & $\begin{array}{r}0.85^{*} \\
(<0.01)\end{array}$ \\
\hline $\mathrm{t} \times \mathrm{t}$ & 1 & $\begin{array}{c}37.72^{*} \\
(<0.01)\end{array}$ & $\begin{array}{c}7.57^{*} \\
(<0.01)\end{array}$ & $\begin{array}{c}0.21^{*} \\
(0.01)\end{array}$ & $\begin{array}{r}0.57^{*} \\
(<0.01)\end{array}$ \\
\hline $\mathrm{t} \times \mathrm{t} \times \mathrm{T}$ & 4 & $\begin{array}{c}0.36 \\
(0.91)\end{array}$ & $\underset{(<0.01)}{0.73^{*}}$ & $\begin{array}{c}0.19 \\
(0.06)\end{array}$ & $\begin{array}{c}0.02 \\
(0.32)\end{array}$ \\
\hline $\begin{array}{l}\text { Total SS } \\
\text { Error }\end{array}$ & $\begin{array}{l}89 \\
65\end{array}$ & $\begin{array}{r}213.52 \\
23.05\end{array}$ & $\begin{array}{r}147.30 \\
1.52\end{array}$ & $\begin{array}{r}72.75 \\
1.36\end{array}$ & $\begin{array}{r}18.37 \\
0.33\end{array}$ \\
\hline $\mathrm{R}^{2}$ & & 0.89 & 0.99 & 0.98 & 0.98 \\
\hline
\end{tabular}

*Statistically significant.

${ }^{1} \mathrm{~T}=$ Temperature of brining.

${ }^{2} \mathrm{~W}=$ Week of cheese making.

${ }^{3} \mathrm{t}=$ Time of brining.

difference in salt concentration between the brine and the aqueous phase of the $\mathrm{P} 1$ portion of the cheese begins to slow down the rate of increase of salt content in portion P1 after about $4 \mathrm{~d}$ of brining and explains the stronger quadratic effect of time in the $\mathrm{P} 1$ portion compared with the other portions (Table 8). Decreased total moisture loss (Figure 2, Table 4) and decreased total salt uptake (Figure 3, Table 4) with decreasing brine temperature were observed in the present study despite the general decrease in porosity near the surface of the blocks that occurred at all temperatures. Thus, brine temperature had a detectable effect that can be seen beyond the large impact of the reduction in porosity at

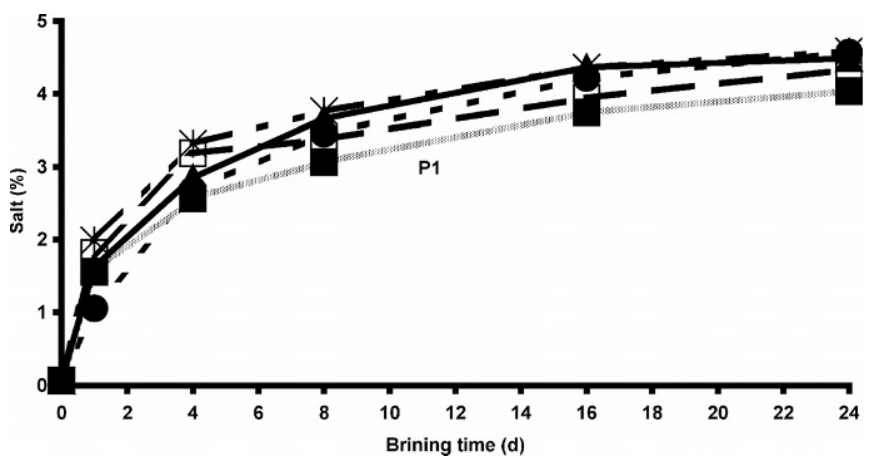

Figure 10. Mean salt (\%) in the P1 portion of the block. Treatments are brine temperatures of $12(\bullet), 15(\square), 18(\boldsymbol{\bullet}), 21(\square)$, and $24^{\circ} \mathrm{C}(*)$. the exterior that was seen in both this and the previous study (Melilli et al., 2003). This is consistent with a separate effect of viscosity vs. porosity, and the results for the effect of brine temperature observed in the present study are consistent with the factors that would increase the viscosity of the aqueous phase of the cheese and retard salt penetration.

\section{Influence of Temperature and Salt on Enzymatic and Microbial Action in Cheese}

In general, as temperature decreases and salt content increases, the rate of action of enzymes involved in

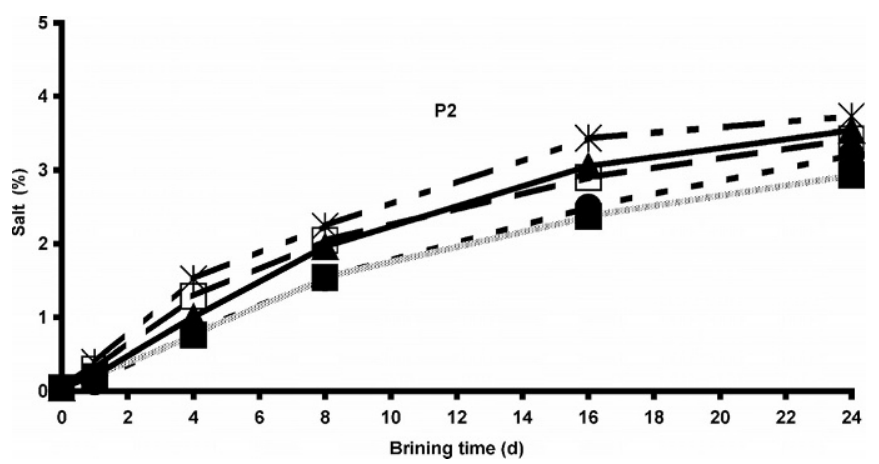

Figure 11. Mean salt (\%) in the $\mathrm{P} 2$ portion of the block. Treatments are brine temperatures of $12(\bullet), 15(\square), 18(\boldsymbol{\Delta}), 21(\square)$, and $24^{\circ} \mathrm{C}(*)$. 


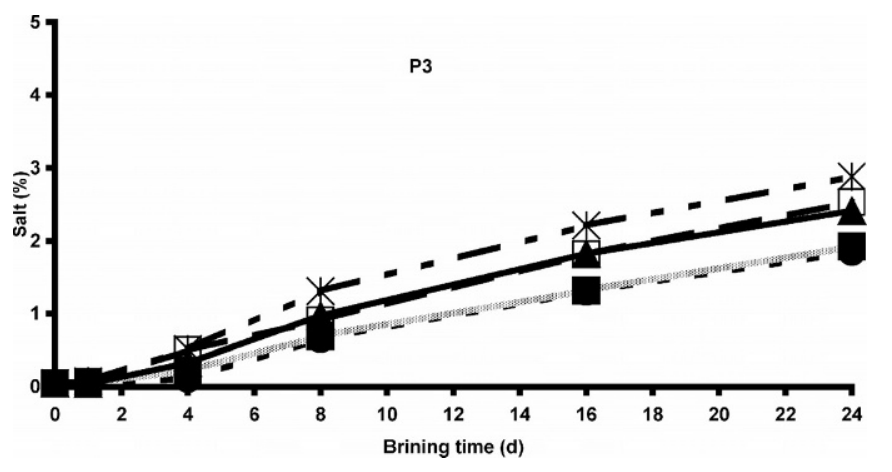

Figure 12. Mean salt (\%) in the P3 portion of the block. Treatments are brine temperatures of $12(\bullet), 15(\square), 18(\boldsymbol{\Delta}), 21(\square)$, and $24^{\circ} \mathrm{C}\left({ }^{*}\right)$.

flavor development decreases and the probability of gas production by undesirable microorganisms decreases. The salt gradient in Ragusano cheese from the surface to the center has been demonstrated to have a large impact on proteolysis, with production of both $\mathrm{pH} 4.6$ and $12 \%$ TCA soluble nitrogen progressively increasing from the exterior (high salt/low moisture) to the center (low salt/high moisture) of the block (Licitra et al., 2000). The level of soluble nitrogen can be as much as twice as high in the center of a 14-kg block of Ragusano cheese than at the surface. The combination of high

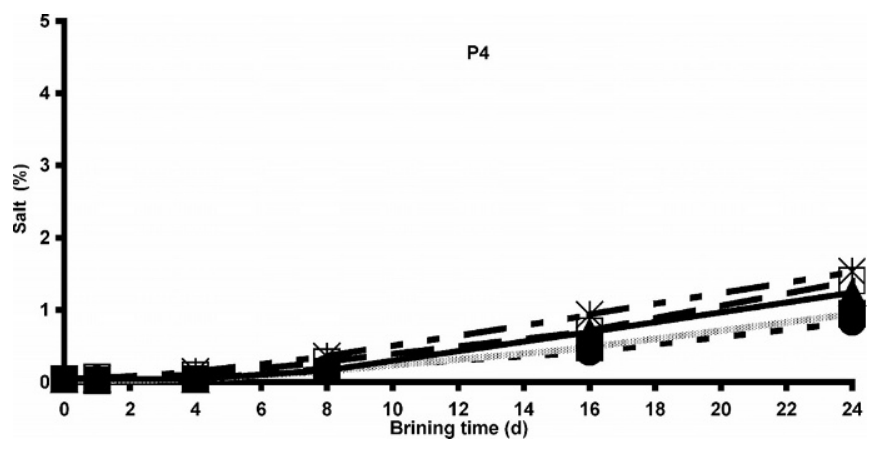

Figure 13. Mean salt (\%) in the P4 portion of the block. Treatments are brine temperatures of $12(\bullet), 15(\square), 18(\boldsymbol{\Delta}), 21(\square)$, and $24^{\circ} \mathrm{C}\left({ }^{*}\right)$.

salt and low moisture produced this effect. As a result, the texture of the cheese progressively changes from the surface to the center of the block. Lipolysis is an important enzymatic process in the production of the typical aged cheese flavor in Ragusano cheese, with FFA concentration in the cheese increasing with time of aging at $18^{\circ} \mathrm{C}$ (Licitra et al., 2000). The impact of salt and moisture gradients on the FFA content of Ragusano cheese at various locations from the surface to the center of the cheese is not known.

The salt and moisture gradients within blocks of brine-salted cheeses also influence the growth of unde-

Table 9. Type III sum of the squares and probability values (in parentheses) for the ANOVA analysis of the impact of brine temperature (T) and time (t) of brining on fat content of cheese portions P1, P2, P3, and P4 within a $15 \times 15 \times 15 \mathrm{~cm}$ block of Ragusano cheese.

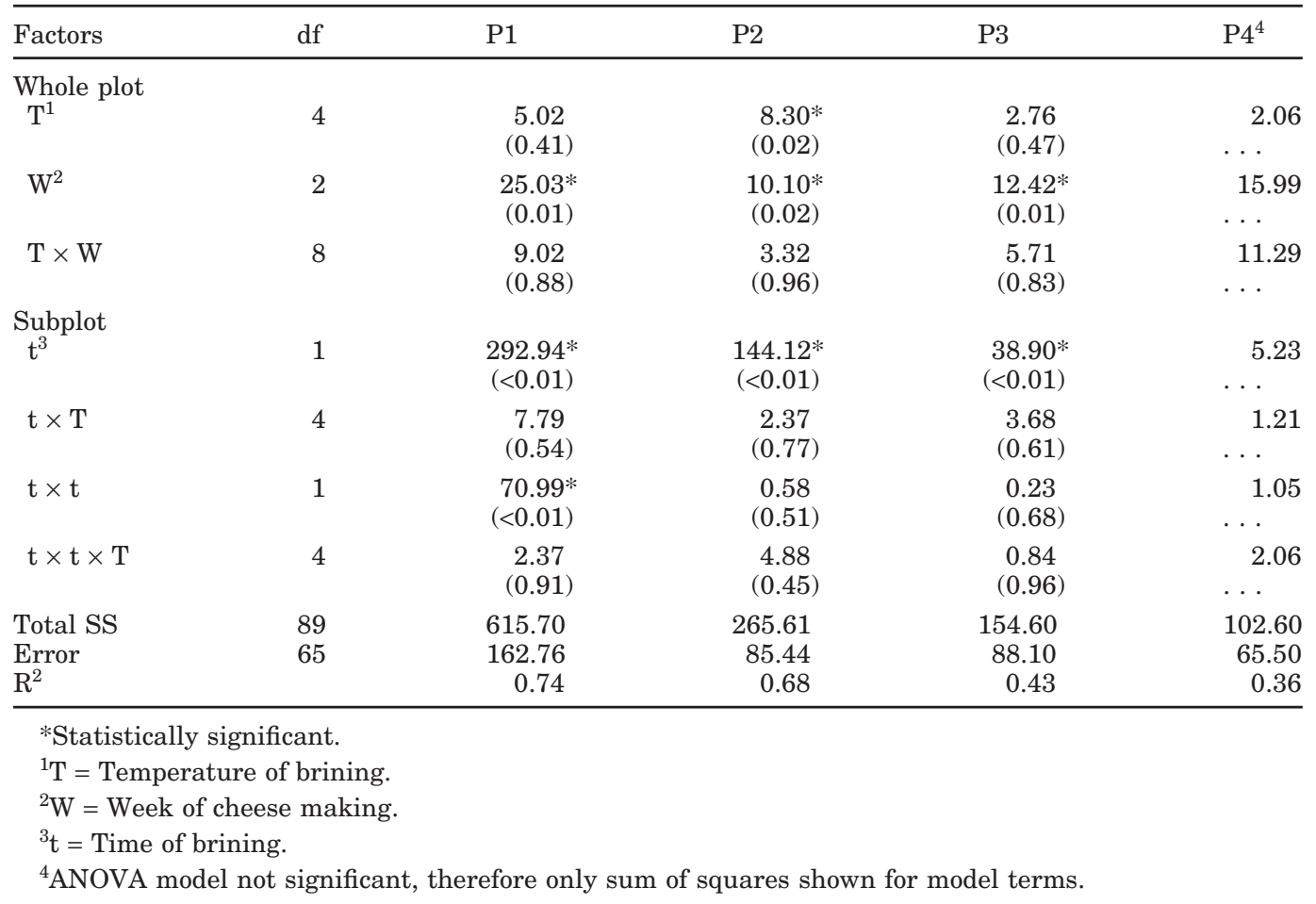


sirable bacteria that can produce gas. Ragusano cheese is typically made from raw milk without the addition of a starter culture (Licitra et al., 1998). Natural microflora, both desirable and undesirable, can be present in the milk and cheese. Undesirable microflora (Escherichia, Aerobacter, and yeasts) can produce early gas defect in cheese (Chapman and Sharpe, 1990). There are many factors that help control the growth of undesirable microflora, and they include sanitation and reduction of undesirable bacterial contamination of milk both at the farm and during the cheese making, proper control of temperature, and rate of acidification by the native lactic acid-producing bacteria during cheese making, lower temperature of aging, and increased rate of salt penetration and concentration of salt in the cheese. The presence of these bacteria in cheese is dependent on the initial contamination level in the milk and their growth is favored by slow acid production during the cheese-making process (Choisy et al., 1987). Coliform bacteria are acid sensitive, and this sensitivity is greater due the combination with other factors such as increasing salt concentration or lower water activity (Choisy et al., 1987). In a previous study (Melilli et al., 2003 ), it was reported that using brine at $18^{\circ} \mathrm{C}$ that was not fully saturated (i.e., 18 vs. $26 \%$ ) doubled the rate of salt penetration into the center (i.e., $\mathrm{P} 4$ portion) of the cheese, so the same salt content was achieved in the center of the cheese in $12 \mathrm{~d}$ instead of $24 \mathrm{~d}$. In the present study using saturated brine, it was observed that reducing brining temperature from 18 to $12^{\circ} \mathrm{C}$ decreased the amount of salt that penetrated to the center of the cheese by about $32 \%$ (Table 7, Figure 13), and therefore it would be expected that at $12^{\circ} \mathrm{C}$ using saturated brine it would take a much longer time of brining to achieve the same salt content in the center of the cheese as when saturated brine and $18^{\circ} \mathrm{C}$ are used for $24 \mathrm{~d}$. The approach of using higher (i.e., 24 vs. $18^{\circ} \mathrm{C}$ ) brine temperature and lower brine concentration (i.e., $18 \%$ vs. saturated) would promote faster salt uptake, but the higher temperature during the first $48 \mathrm{~h}$ of brining would probably promote the rapid growth of gas producing organisms in the center of the block, where the salt concentration would still be very low (Figure 13). The data in the present study is for $3.5-\mathrm{kg}$ blocks, so the time for penetration of salt to the center of the block (in the full size 15-kg blocks) would probably make this combination of conditions (i.e., high brine temperature and low brine concentration) unsuccessful in reducing gas problems. It is difficult to predict exactly from the data in the previous (Melilli et al., 2003) and the present study what the combined effect of a reduction in brine concentration and brine temperature would be on salt penetration to the center of the cheese and on gas production. It is possible that the combina- tion of lower salt concentration in brine and lower brine temperature could achieve the same salt concentration in the center of the cheese in $24 \mathrm{~d}$ and provide an additional benefit of slowing the growth of undesirable gas producing bacteria.

\section{CONCLUSIONS}

Ragusano cheese is normally salted in saturated brine at $18^{\circ} \mathrm{C}$. Decreasing the temperature (from 24 to $12^{\circ} \mathrm{C}$ ) of saturated brine used for brine salting in the present study, decreased the rate of salt uptake by the blocks of cheese, but the reduction in the amount of salt penetration due to decreasing brine temperature from 18 to $12^{\circ} \mathrm{C}$ in the present study was not as large as the increase in the rate of salt penetration due to decreasing brine concentration (from saturated to 18\%) observed in the previous study (Melilli et al., 2003). It was concluded that the decrease in salt penetration at lower brine temperature was caused by an increase in viscosity of the water phase of the cheese, whereas the mechanism of the impact of changing brine concentration was due an impact on the porosity of the cheese. As brine concentration increases, porosity of the cheese at the surface decreases and impedes salt penetration. During the first few days of brine salting, the porosity near the surface of all cheeses at all brining temperatures decreased due to the large decrease in moisture content. Because the impact of brining temperature on salt penetration was due to a mechanism other than a change in porosity of the cheese, it was possible to detect the impact of brining temperature on rate of salt penetration even when the porosity near the surface of the cheeses at all brining temperatures was decreasing.

Decreasing brine temperature can reduce the growth and gas production by undesirable microorganisms in the cheese. The relative impact of higher salt concentration versus lower temperature of brining on gas production by undesirable microorganisms will probably vary depending on the specific type(s) of gas-producing organism present. It may be possible with a combination of a reduction in brine concentration plus a lower brining temperature to achieve the same total salt penetration into the center of cheese in the same amount of time during brining, but to accomplish it at a lower temperature. This could reduce the probability of early gas defect development in Ragusano cheese.

\section{ACKNOWLEDGMENTS}

The authors thank Mario Manenti, Giovanni Farina, Rosario Tumino, Giuseppe Schembari, Sebastiano Campo, Giovanni Longombardo, Glenda Leto, Antonio Difalco, and Patrizia Campo for their technical assis- 
tance in cheese manufacture and cheese analysis. Financial support was provided by the Assessorato Agricoltura e Foreste della Regione Siciliana, Palermo, Italy.

\section{REFERENCES}

Association of Official Analytical Chemists International. 2000. 17th ed. Official Methods of Analysis. AOAC International, Gaithersburg, MD.

Carić, M. 1993. Ripened cheese varieties native to Balkin countries. Pages 263-280 in Cheese Chemistry, Physics, and Microbiology, Vol. 2., Major Cheese Groups. P. F. Fox, ed. 2nd ed. Chapman and Hall, London.

Chapman, H. R., and M. E. Sharpe. 1990. Microbiology of cheese. Pages 203-289 in Dairy Microbiology. Vol. 2. R. K. Robinson, ed. Elsevier, London.

Choisy, C., M. Gueguen, J. Lenoir, J. L. Schmidt, and C. Tourneur. 1987. The ripening of cheese: microbiological aspects. Pages 250 292 in Cheesemaking-Science and Technology. A. Eck, ed. Lavoisier Publ. Inc., New York.

Geurts, T. J., P. Walstra, and H. Mulder. 1974. Transport of salt and water during salting of cheese. 1 . Analysis of the processes involved. Neth. Milk Dairy J. 28:102-129.

Geurts, T. J., P. Walstra, and H. Mulder. 1980. Transport of salt and water during salting of cheese. 2. Quantities of salt taken up and moisture lost. Neth. Milk and Dairy J. 34:229-254.

Glantz, S. A., and B. K. Slinker. 2001. Multicolinearity and what to do about it. Pages 185-187 in Primer of Applied Regression \& Analysis of Variance. 2nd ed. McGraw-Hill, Inc. New York.

Guinee, T. P., and P. F. Fox. 1983. Sodium chloride and moisture changes in Romano-type cheese during salting. J. Dairy Res. 50:511-518.

Guo, M. R., and P. S. Kindstedt. 1995. Age-related changes in the water phase of Mozzarella cheese. J. Dairy Sci. 78:2099-2107.

Guo, M. R., J. A. Gilmore, and P. S. Kindstedt. 1997. Effect of sodium chloride on the serum phase of Mozzarella cheese. J. Dairy Sci. 80:3092-3098.
Kindstedt, P. S., and F. V. Kosikowski. 1985. Improved complexometric determination of calcium in cheese. J. Dairy Sci. 68:806-809.

Licitra, G., G. Portelli, P. Campo, G. Longombardo, G. Farina, S. Carpino, and D. M. Barbano. 1998. Technology to produce Ragusano cheese: A survey. J. Dairy Sci. 81:3343-3349.

Licitra, G., P. Campo, M. Manenti, G. Portelli, S. Scuderi, S. Carpino, and D. M. Barbano. 2000. Composition of Ragusano cheese during aging. J. Dairy Sci. 83:404-411.

Luna, J. A., and M. S. Chavez. 1992. Mathematical model for water diffusion during brining of hard and semi-hard cheese. J. Food Sci. 57:55-58.

Melilli, C., D. M. Barbano, G. Licitra, G. Tumino, G. Farina, and S. Carpino. 2003. Influence of presalting and brine concentration on salt uptake by Ragusano cheese. J. Dairy Sci. 86:1083-1100.

Payne, M. R., and K. R. Morison. 1999. A multi-component approach to salt and water diffusion in cheese. Int. Dairy J. 9:887-894.

Payens, T. A., J. 1979. Association of caseins and their possible relation to structure of the casein micelle. J. Dairy Sci. 49:1317-1324.

Quiñones, H. J., D. M. Barbano, and L. G. Phillips. 1997. Influence of protein standardization by ultrafiltration on the viscosity, color and sensory properties of skim and $1 \%$ milk. J. Dairy Sci. 80:3142-3151.

Quiñones, H. J., D. M. Barbano, and L. G. Phillips. 1998. Influence of protein standardization on the viscosity, color, and sensory properties of $2 \%$ and $3.3 \%$ fat milks. J. Dairy Sci. 81:884-894.

Resmini, P., G. Volonterio, S. Annibaldi, and G. Ferri. 1974. Studio sulla diffusione del sale nel formaggio Parmigiano-Reggiano mediante l'uso di $\mathrm{Na}^{36} \mathrm{Cl}$. Sci. Tecn. Latt. Casearia 25:149-166.

Turhan, M., and G. Kaletunç. 1992. Modelling of salting diffusion in white cheese during long term brining. J. Food Sci. 57:1082-1085.

Turhan, M., and S. Gunasekaran. 1999. Analysis of moisture transfer in white cheese during brining. Milchwissenschaft 54:446-450.

Walstra, P., T. J. Geurts, A. Noomen, A. Jellema, and M. A. J. S. van Boekel. 1999. Pages 145-146 in Dairy Technology: Principles of Milk Properties and Processes. Marcel Dekker, Inc. New York.

Zorrilla, S. E., and A. C. Rubiolo. 1991. Average $\mathrm{NaCl}$ concentration in cheese for different volume ratios of brine and solid during salting. J. Food Sci. 56:1548-1551. 